\title{
喜界島における鳥の巣の捕食：営巣環境による捕食率の違いと 捕食者の特定
}

\author{
坂上 舞 ${ }^{1, *} \cdot$ 濱尾章二 $^{2} \cdot$ 森 貴久 ${ }^{1}$ \\ 1 帝京科学大学生命環境学部動物生態学 ·行動学研究室 干 409-0193 山梨県上野原市八ツ沢 2525 \\ 2 国立科学博物館附属自然教育園 干 108-0071 東京都港区白金台 5-21-5
}

(2010 年 2 月 26 日受付；2011 年 1 月 6 日受理)

キーワード : 移入哺乳動物, 営巣環境, 喜界島, 擬巣実験, 巣の捕食.

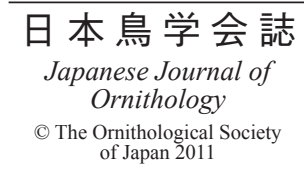

日本鳥学会誌 Ornithology of Japan 2011

Mai Sakagami ${ }^{1, *}$, Shoji Hamao ${ }^{2}$, Yoshihisa Mori ${ }^{1}$. 2011. Predation of bird nests on Kikai Island, in the Amami Island group: differences in predation rates among nesting habitats and the identity of predators. Jpn. J. Ornithol. 60: 88-95.

\begin{abstract}
We carried out an artificial nest experiment to investigate differences in predation rates of bird nests among different habitats and to identify predators on Kikai Island, in the Amami Island group. Both the proportion of depredated nests and the probability of survival showed that nests in forests suffered predation more frequently than nests in bushes and grasslands. Artificial nests with automatic image recording systems revealed that two introduced mammals (i.e., Black rat Rattus rattus and Japanese Weasel Mustela itatsi) and the indigenous Jungle Crow Corvus macrorhynchos were predators. Neither the degree of concealment of individual nests nor the distance between nests was found to have a significant relationship with predation. It is possible that frequent nest predation in forests results from the abundance and habits of each predator species.
\end{abstract}

Key words: Introduced mammals, Nesting habitat, Kikai Island, Artificial nest experiment, Nest predation.

1 Laboratory of Animal Ecology and Behavior, Teikyo University of Science and Technology, 2525 Yatusawa, Uenohara City, Yamanashi 409-0193, Japan.

${ }^{2}$ The Institute for Nature Study, National Museum of Nature and Science, 5-21-5 Shiroganedai, Minato-ku, Tokyo 108-0071, Japan.

\section{はじめに}

島嶼においては，人為的に移入した動物が在来 の生物を捕食し, 個体群の維持に影響を与えるこ とが知られている (Dutton 1994, Courchamp et al. 2003, Blackburn et al. 2004). 鳥類に関しては, 伊 豆諸島の三宅島でニホンイタチ Mustela itatsi 導入 によってアカコッコ Turdus celaenops の減少した 例が知られており（高木ら 1992），沖縄島では人 為的に導入されたマングース Herpestes javanicus が

\footnotetext{
*E-mail: woodstock8198@yahoo.co.jp
} doi: $10.3838 /$ jjo. 60.88 JOI:JST.JSTAGE/jjo/60.88
ヤンバルクイナ Gallirallus okinawae を捕食するこ とが危惧されている（尾崎 2002）。島嶼は独自の 生物相をもち，固有種や固有亜種が生息すること があるが，全体としては生息種数が少なく鳥類の 捕食者となる種を欠くことが多いため，島嶼に生 息する鳥類は捕食者に対する適応があまり進化し ていない (Courchamp et al. 2003, Blackburn et al. 2004)。そのために, 在来鳥類の生息にとって, 人 為的に移入された捕食動物は大きな务威となる. また，移入された捕食動物の生息環境の選好性に よっては，特定の生息環境を利用する鳥類が強く 影響を受けることが考えられる。そのため, 島嶼 に移入された動物による鳥類の巣の捕食圧を異な 
る環境間で比較することは重要である.

奄美諸島喜界島には, 森林, 藪, 草原の三つの 代表的な環境がある。森林にはメジロ（亜種リュ ウキュウメジロ Zosterops japonicus loochooensis), 藪にはウグイス（亜種ダイトウウグイス Cettia diphone restricta), 草原にはセッカCisticola juncidis と, この地域の特産亜種を含む鳥類がそれぞれの 環境に対応して生息している。

喜界島は島全体が数段の隆起サンゴ礁からなる サンゴ礁段丘の島である。島は形成途中に海水面 の上昇により海に覆われた後, 海水面の下降と陸 地の隆起によって形成されたため（安間 2001）, 哺乳類やへビ類の移入はなく, 本来それらは生息 していない。しかし，島には人為的な分布と考え られるネズミ類 Muridae（金子 2006）や野ネズミ 駆除対策のために 1942 年に人為的導入されたニホ ンイタチ（三井 1965, Uchida 1969）が生息してい る。これらの移入種が鳥類の巣の卵や雛の捕食者 となり，鳥類の個体群の維持に影響を及ほしてい る可能性が考えられる，実際にウグイス（濱尾 2009), メジロ (濱尾 個人的観察) では, 巣の捕 食が確認されている。しかし巣を捕食した動物は 特定されておらず，ネズミ類やニホンイタチが在 来鳥類の巣を襲うのかどうかは明らかでない，そ こで, 本研究では, 人工巣 (擬巣) と無人撮影装 置を使用し，喜界島に扮ける巣の捕食者を特定す ることを目的とした。

巣が捕食を受けやすいかどうかは, 営巣場所の 植生などの営巣環境に影響を受ける (Whittingham \& Evans 2004)。そのため, 島の中でも捕食性動物 の生息密度や捕食行動から捕食の影響を受けやす い営巣環境，またその環境に生息し影響を受けや すい鳥類がいることが考えられる，そこで本研究 では, 喜界島の代表的な営巣環境である森林, 藪, 草原の間で，巣の捕食の受けやすさが異なるかど うかを擬巣実験で明らかにする。また，個々の巣 の捕食の受けやすさには，それぞれの巣場所の特性 が影響する。巣の隠蔽度 (Ueta 1998, Kleindorfer $e t$ al. 2003, Mizuta 2009) と巣間の距離（Martin 1988, Martin et al. 2000, Hamao et al. 2009）は捕食に関わ る重要な要因である。そこで, 擬巣の隱蔽度と巣 同士の距離が捕食の生起に関わっているかどうか も調査した。これらの結果から, 島嶼に移入され た捕食性動物の在来鳥類の繁殖に対する影響を考 察する。

\section{方法}

\section{1) 調査地}

喜界島（面積 $56.94 \mathrm{~km}^{2}$ ) は九州本土から南約 $380 \mathrm{~km}$ に位置する奄美諸島の一つである。調査は 島内の荒木地区 $\left(28^{\circ} 18^{\prime} \mathrm{N}, 129^{\circ} 55^{\prime} \mathrm{E}\right.$, 標高 $27 \sim 33$ $\mathrm{m})$, 手久津久地区 $\left(28^{\circ} 17^{\prime} \mathrm{N}, 129^{\circ} 56^{\prime} \mathrm{E}\right.$, 標高 19 $50 \mathrm{~m})$ 周辺で 2009 年 6 月 8 日から 6 月 26 日まで 行った，喜界島を代表する鳥類の生息環境は，森 林, 藪, そして畑周辺の草原である。調査地では 農道に沿って数 $10 \mathrm{~m}$ 四方を 1 区画とする畑が連 続し，その間に 10〜20 m（時に $50 \mathrm{~m}$ ）の幅の森 林や畑の周囲に小面積の草原が散在していた。森 林は種々の常緑広葉樹からなる二次林で, 樹冠の 高さは 7 10 m（時に $12 \mathrm{~m}$ ) であった. 藪は野生 化したネピアグラス Pennisetum purpureum が成長 し (草高約 2〜 m $)$, 竹のようになって密生して いるものである。草原は若いネピアグラスなどの イネ科植物（草高約 $80 \mathrm{~cm}$ ) からなる.

\section{2）擬巣実験}

擬巣はペットの小鳥を飼育するための市販のつ ぼ巣を利用し, 深さを浅くし, 入り口の直径を広 くしたもの（直径約 $8 \mathrm{~cm}$, 奥行き約 $9 \mathrm{~cm}$ ）を用い た。巣の中にはウズラの卵を 2 個入れ, 森林, 藪, 草原の三つの営巣環境に各 30 個ずつ, 計 90 個設 置した、巣の設置は, ある環境に 1 個の巣を設置 したらまだ巣を設置していない方向へ $50 \mathrm{~m}$ 歩き, その場所にあった環境に次の巣を設置した（図 1). したがって, 擬巣を設置した三つの環境は地 域内に混在したが, 一部では同じ環境（例えば森 林）が広い面積を占めていたため, 複数の擬巣が 同じ環境に続けて設置された場合もある。個々の 巣は, 環境ごとに喜界島に生息する鳥の営巣場所 を模した高さに設置した。森林ではメジロを模し 地上から $2 \mathrm{~m}$, 藪ではウグイスを模し地上から $80 \mathrm{~cm}$, 草原ではセッカを模し地上から $60 \mathrm{~cm}$ に設 置した，巣の設置期間はそれぞれの種の抱卵期間 （メジロは11〜12 日，ウグイスは 14 日，七ッカは 14 日）を参考にして 14 日間とした。営巣場所と 抱卵期間は清棲（1978）を参考にした。設置した 巣は3 日ごとに訪れ，巣内の卵の有無を記録した。 巣の中に入っている卵 2 個のうち，1個でも卵が 消失した場合，巣の中に卵殼が残っている場合， 動物による噛み傷がついている卵が確認された場 合に捕食が起きたとみなした。 


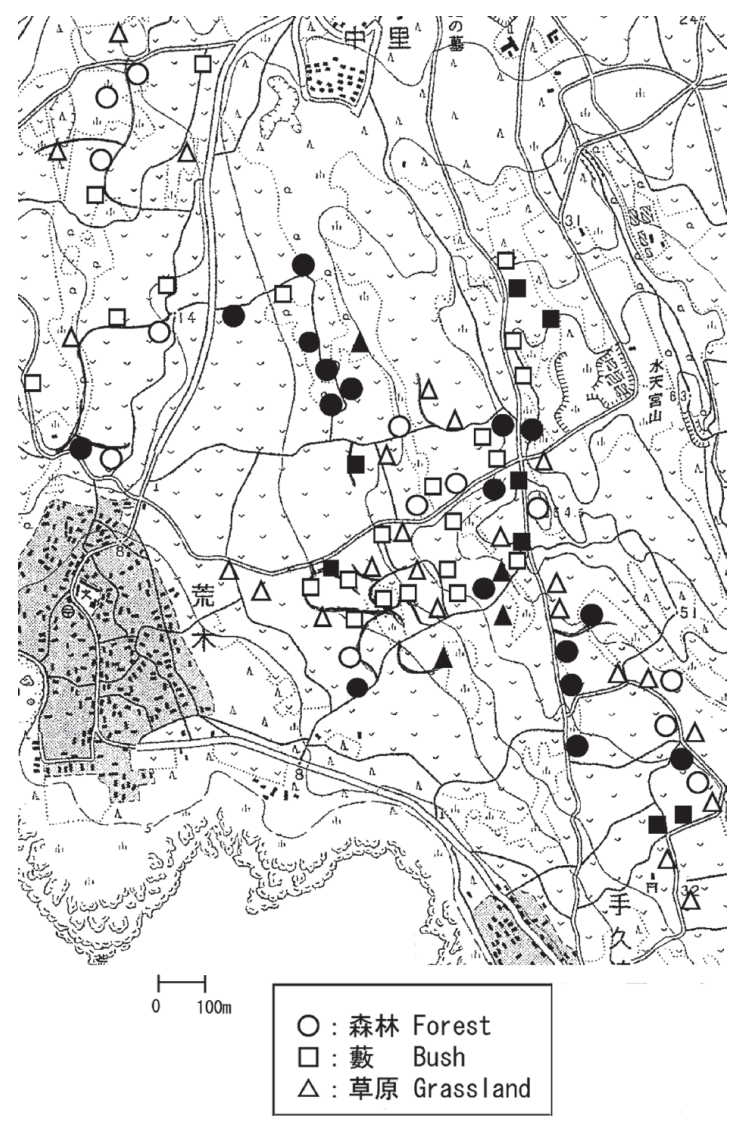

図 1. 調査地と擬巣の設置場所。鳥類の営巣環境ごとに 異なる印で擬巣設置地点を示した。黒塗りは捕食された 擬巣，白抜きは捕食されなかった擬巣を示す。この地図 は, 国土地理院発行の 2 万 5 千分の 1 地形図 (喜界島南 部）を使用したものである.

Fig. 1. Study area and locations of artificial nests. Solid and open marks indicate depredated and non-depredated nests, respectively. The map used here is taken from a $1 / 25000$ topographical map (of the southern part of Kikai Island) with permission from the Geographical Survey Institute.

巣の隠蔽度を表すため, 各々の擬巣の見えやす さを上からと横からについて測り記録した。 上か らの見えやすさは擬巣からデジタルカメラを上に 向け，写真を撮った。 そして画像処理ソフト (Windows 用汎用画像処理パッケージ Win Roof) を使用し，写真に写る空の割合（\%）を算出した。 横からの見えやすさは，擬巣と同じくらいの大き さである，一辺 $9 \mathrm{~cm}$ の立方体を巣の上に乗せ，そ れを観察して測定した，立方体のそれぞれの面に $1.5 \mathrm{~cm}$ ごとに線を引き， 36 個 $(6 \times 6)$ の正方形を 描いた。これを互い違いに（市松模様状に）赤く 塗り，赤い正方形が何個見えたかを観察した。観 察は, $1 \mathrm{~m}$ 離れた場所の 4 方向から行い, 4 方向 から見えた赤い正方形の合計数 $(0 ７ 2)$ を見えや すさのスコアとした。
巣同士の距離は, それぞれの擬巣について, 最も 近い捕食された巣までの距離を地図上で測定した。

\section{3）捕食者の撮影}

捕食者の撮影はフィルムセンサーカメラ (FieldNote 麻里府商事）9台，デジタルセンサーカメラ (Game Spy I40, Moultrie 社) 2 台, ビデオカメラ （CCD-TRV126, Sony）1台を使用して行った。 セ ンサーカメラは擬巣設置時に森林に 4 台, 藪に 4 台，草原に 3 台を三つの環境にそれぞれなるべく 離れた場所に設置した，捕食が確認された巣にカ メラが設置されていなかった場合には，ウズラの 卵を再度その巣に入れ, カメラを他所から移動し て設置した。卵の追加は，他の巣の捕食に影響が ないよう，2 回までとした。2 回卵の追加をした巣 のカメラは, また次の捕食が起こった巣へと移動 させ，撮影をした，ビデオカメラは捕食が確認さ れた巣に設置した。 センサーカメラとビデオカメ ラは共に日中に設置し, 翌日の午前中または日中 に卵の捕食の有無を確認した。

\section{4）分析方法}

森林・藪・草原の環境間で捕食の受けやすさを 検討するために，二つの解析を行った。一つは, 捕食された巣の割合の比較である。実験期間中に 捕食された巣の個数から，環境ごとに巣の捕食さ れた割合を算出した。捕食された巣の個数には, 捕食者撮影のために追加した卵の捕食は含めてい ない，捕食された巣の割合が三つの環境によって 異なるかどうか調べる際は, カイ二乗検定を用い た，検定の際，草原では実験期間中に 2 つの擬巣 が刚り取られてしまったため, この2つの巣を除 いた巣の数 $(N=28)$ で検定を行った. もう一つ の解析は, Mayfield 法 (Mayfield 1961, 1975) によ る 1 日あたりの巣の生残確率を用いたものである. この解析では, 巣を設置しておいた日数 (nest exposure days）に対する捕食の起きた日数の割合 から，1日あたりに巣が捕食される確率を求める. 森林・藪・草原それぞれの環境について, 個々の 巣が捕食されるまでの日数の総和 (total nest-days) に対する捕食が起きた日数（=捕食が起きた巣数） の割合を求め, これを 1 から減じた值を 1 日あた りの巣の生残確率とした。ただし, 捕食の有無を 確認したのは 3 日ごとであったので, 捕食される までの日数は捕食を認めた確認日と前の確認日の 中間とした（6日目に捕食を確認した場合 4.5 日）.

環境による 1 日あたりの生残確率の違いを調べ 


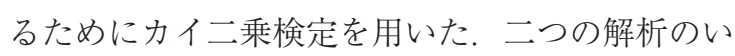
ずれでも，二つの環境間の比較を行う場合には， 多重比較の問題が生じるため Bonferroni の補正 （Rice 1989）を行った。

巣同士の距離は, 擬巣実験の結果から, 捕食さ れなかった巣と最も近い捕食された巣の距離と捕 食された巣と最も近い捕食された巣同士の距離を 測り比較した，巣の見えやすさを捕食された巣と されなかった巣で比較する際，また捕食された巣 までの距離を捕食された巣とされなかった巣で比 較する際には, Kruskal-Wallis 検定と Mann-Whitney の $U$ 検定を用いた。

\section{結果}

\section{1）営巣環境と捕食率}

14 日間に捕食された擬巣の割合は森林が $56.7 \%$ $(N=30)$, 藪 が $26.7 \% \quad(N=30)$, 草原が $14.3 \%$ $(N=28)$ であった，森林は草原と藪よりも捕食さ れた巣の割合が有意に高かった（森林と草原 : $\chi_{1}^{2}=$ 11.26, $P<0.01$ [補正後の值]; 森林と藪: $\chi_{1}^{2}=5.55$, $P<0.05$ [補正後の值]). 藪と草原の間には捕食され た巣の割合に差はなかった $(P>0.20)$. 1 日あたり の巣の生残確率は森林が 0.942 (total nest-days = 291), 藪が 0.976 (total nest-days $=338)$, 草原が 0.989 （total nest-days = 360）であった，草原は森林 に対して生残する割合が有意に高かった（森林と草 原 : $\chi_{1}^{2}=11.54, \quad P<0.01$ [補正後の值]; 図 2). 藪 は森林に対して生残する割合が高い傾向があった が，統計上有意なものではなかった（森林と藪： $\chi_{1}^{2}=4.95,0.05<P<0.10$ [補正後の值]; 図 2).

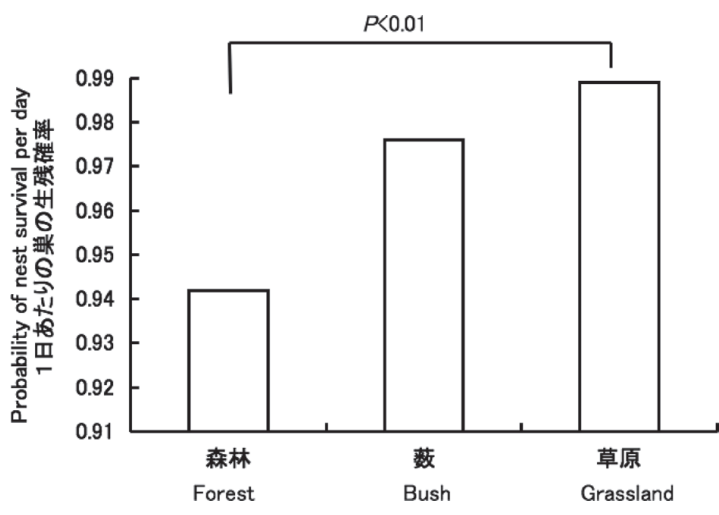

図 2. 巣の生残確率と環境との関係.

Fig. 2. Relation between probability of nest survival and habitat.

巣の隠蔽度を上からと横からの見えやすさで表 した，上からの見えやすさは三つの環境の間で差 があり $\left(N_{1}=30\right.$ [森林 $], N_{2}=30$ [藪 $], N_{3}=28$ [草 原], $H=46.81, P<0.001)$, 草原で最も見えやす く, 続いて藪, 森林であった（森林と藪： $U=$ $192.5, \quad P<0.001$; 森林と草原 : $U=28, \quad P<0.001$; 藪と草原：U=133, $P<0.001 ; P$ 值は Bonferroni の 補正後のもの; 表 1$)$. 横からの見えやすさも三つ の環境の間で差があり $\left(N_{1}=30\right.$ [森林 $], N_{2}=30$ [藪], $N_{3}=28$ [草原], $\left.H=64.78, P<0.001\right)$, 森林 で最も見えやすく, 続いて藪, 草原であった（森 林と藪 : $U=11.5, \quad P<0.001$; 森林と草原 : $U=0$, $P<0.001$; 藪と草原: $U=162, \quad P<0.001 ; P$ 值は Bonferroni の補正後のもの)。捕食を受けた巣と受 けなかった巣の隠蔽度を比較すると, 上からの見 えやすさについては, 森林, 藪, 草原のいずれに おいても捕食された巣とされなかった巣で見えや

表 1. 巣の隠蔽度と捕食の関係。それぞれの環境について, 平均土標準偏差, 範囲を示した。

Table1. Relationship between nest concealment and predation. Mean \pm S.D. and range are shown.

\begin{tabular}{|c|c|c|c|c|c|}
\hline & $\begin{array}{c}\text { 環境 } \\
\text { Habitat }\end{array}$ & $\begin{array}{c}\text { 捕食された巣 } \\
\text { Depredated nests }\end{array}$ & $\begin{array}{l}\text { 捕食されなかった巣 } \\
\text { Non-depredated nests }\end{array}$ & $U$ & $P$ \\
\hline \multirow{4}{*}{$\begin{array}{l}\text { 上からの見えやすさ } \\
\text { Vertical visibility }\end{array}$} & 森林 & $3.8 \pm 2.7 \quad(N=17)$ & $3.7 \pm 2.4(N=13)$ & 103 & 0.75 \\
\hline & Forest & $1.0-13.1$ & $1.7-9.9$ & & \\
\hline & $\begin{array}{c}\text { 藪 } \\
\text { Bush }\end{array}$ & $\begin{array}{c}6.1 \pm 3.5(N=8) \\
2.4-11.6\end{array}$ & $\begin{array}{c}8.5 \pm 6.2(N=22) \\
1.7-25.7\end{array}$ & 67 & 0.32 \\
\hline & $\begin{array}{c}\text { 草原 } \\
\text { Grassland }\end{array}$ & $\begin{array}{c}33.1 \pm 13.8(N=4) \\
17.2-50.8\end{array}$ & $\begin{array}{c}20.2 \pm 13.8 \quad(N=24) \\
4.1-54.4\end{array}$ & 23 & 0.10 \\
\hline \multirow{4}{*}{$\begin{array}{l}\text { 横からの見えやすさ } \\
\text { Horizontal visibility }\end{array}$} & 森林 & $57.6 \pm 10.6 \quad(N=17)$ & $58.6 \pm 7.2(N=13)$ & 110 & 0.98 \\
\hline & Forest & $38-71$ & $40-67$ & & \\
\hline & $\begin{array}{c}\text { 藪 } \\
\text { Bush }\end{array}$ & $\begin{array}{c}22.0 \pm 12.6(N=8) \\
6-41\end{array}$ & $\begin{array}{c}27.0 \pm 11.1 \quad(N=22) \\
3-43\end{array}$ & 65.5 & 0.29 \\
\hline & $\begin{array}{c}\text { 草原 } \\
\text { Grassland }\end{array}$ & $\begin{array}{c}12.0 \pm 7.3(N=4) \\
2-19\end{array}$ & 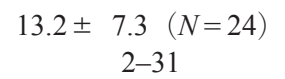 & 47.5 & 0.97 \\
\hline
\end{tabular}


すさに差は見られなかった（表 1)。また横からの 見えやすさにおいても, 森林, 藪, 草原のいずれ に拈いても捕食された巣とされなかった巣の間で 見えやすさに差は見られなかった（表 1)。このよ うに, 巣の隠蔽度は三つの環境すべてにおいて, 捕食された巣と捕食されなかった巣の間で違いが 見られなかった。

捕食された最も近い巣からの距離を捕食された 巣とされなかった巣で比較した。調査地全体では, 距離は捕食された巣で $94.2 \pm 71.7 \mathrm{~m}$ (平均土標準 偏差； $N=29)$, 捕食されなかった巣で $153.9 \pm$ $138.8 \mathrm{~m}(N=59)$ と捕食された巣の方が短かった $(U=568, P<0.05)$. 三つの営巣環境に分けてみる
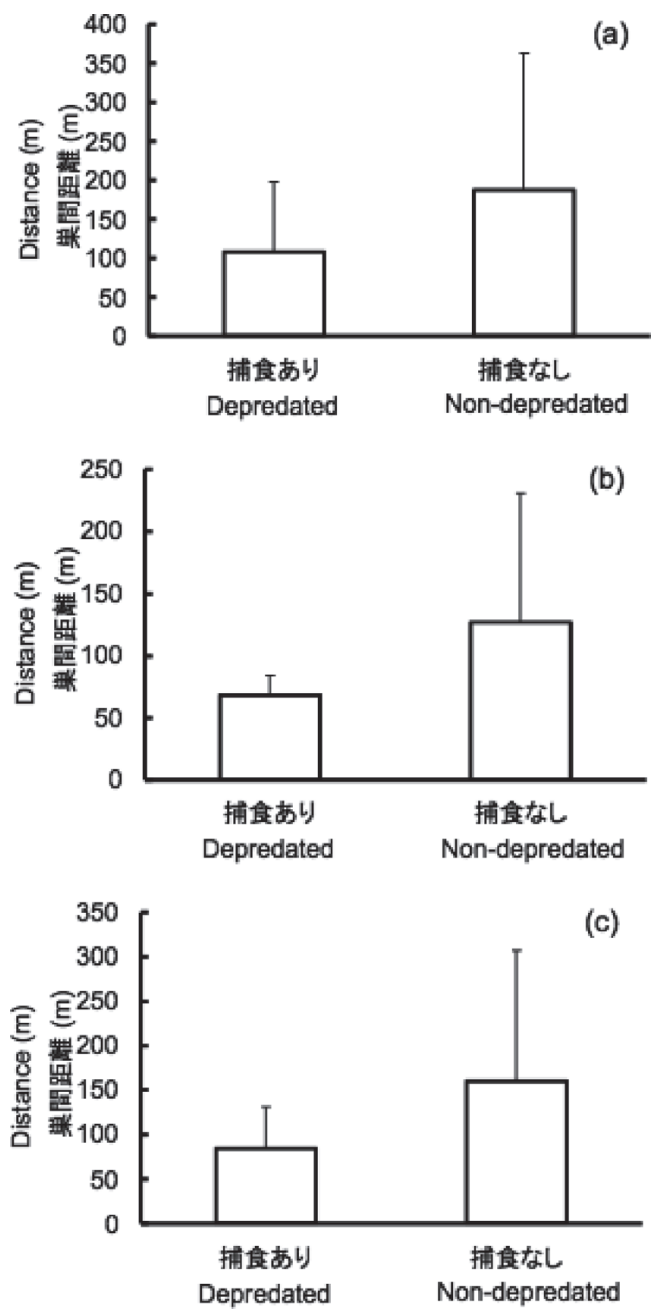

図 3. 捕食と巣間距離の関係。巣間距離は, 捕食された 巣のうちで最も近いものまでの距離とした。(a) 森林, (b) 藪, （c）草原。平均土標準偏差を示した。

Fig. 3. Relation between nest predation and distance to depredated nests. The distance was measured from a nest to the nearest nest that was depredated. (a) forest, (b) bush, (c) grassland. Means and S.D. are shown.
と, 捕食された巣の方がされなかった巣よりも, 捕食された巣までの距離が短い傾向があった（図 3) ものの, 統計上有意な差はなかった（森林： $N_{1}=$ 17, $N_{2}=13, U=73.5, P=0.12$; 藪 : $N_{1}=8, N_{2}=$ $22, U=53, P=0.10$; 草原 : $N_{1}=4, N_{2}=24, U=$ 26, $P=0.15)$.

\section{2）捕食者の撮影}

調査期間中に，6ヶ所の擬巣で動物が撮影され た. センサーカメラにより森林 1 ケ所でハシブト
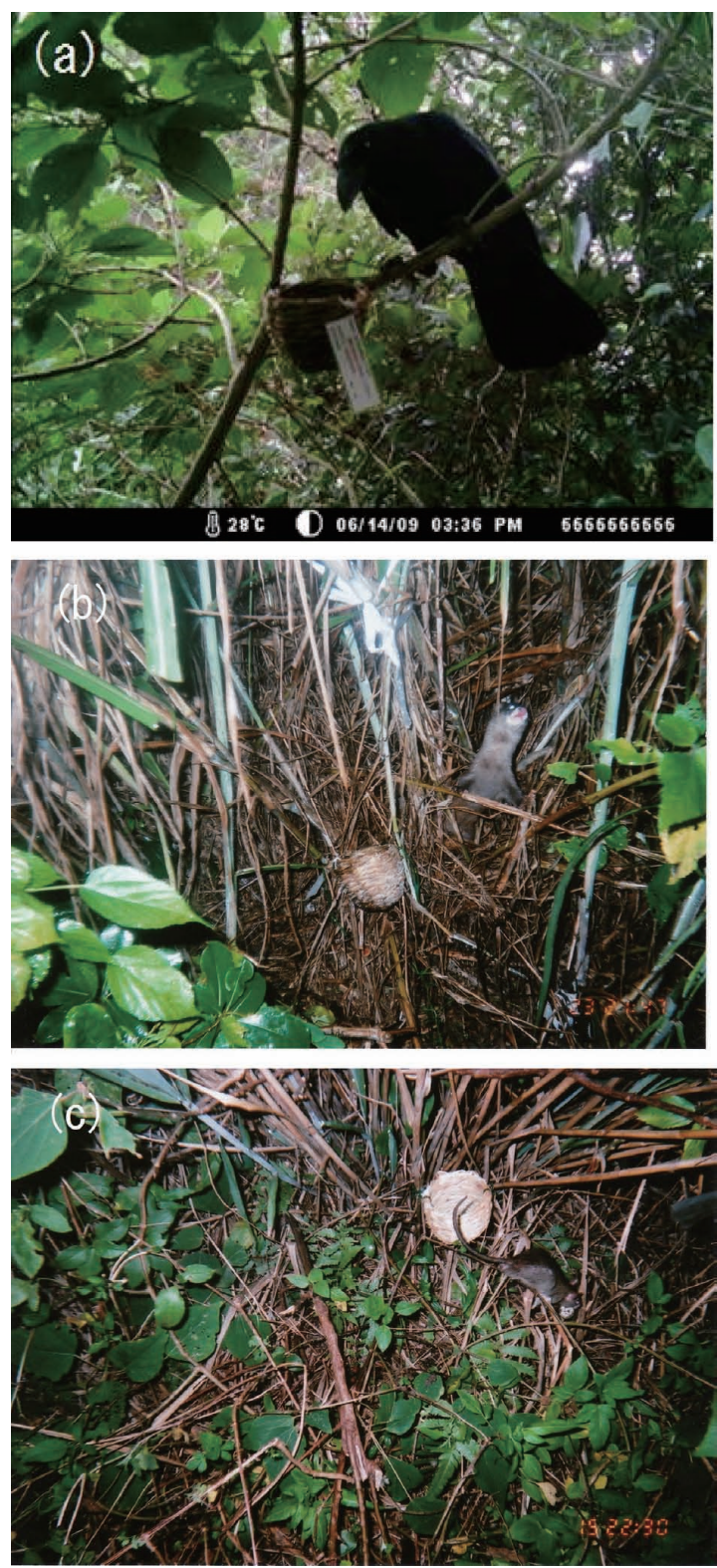

図 4. 擬巣を訪れた動物の撮影例. (a) ハシブトガラス (森林), (b) 二ホンイタチ (藪), (c) クマネズミ (草原). Fig. 4. Examples of potential predators visiting artificial nests. (a) A Jungle Crow in a forest, (b) A Japanese Weasel in a bush, (c) A Black Rat in a grassland. 
ガラス Corvus macrorhynchos とクマネズミ Rattas rattas, 藪4ヶ所のうち3ケ所でニホンイタチ，1ケ 所でクマネズミ，草原1ヶ所でクマネズミが撮影 された（図 4). またビデオカメラでは藪でのニホ ンイタチが撮影された。二ホンイタチは実際に調 查期間中, 調查地内の4ヶ所で姿を確認した。撮 影された動物のうち草原のクマネズミ，藪の二ホ ンイタチのそれぞれ 1 例では巣の中の卵を持ち去 る様子が撮影されていたが，他の例では巣を訪れ た動物が卵を捕食したり持ち去ったりする様子は 撮影されていなかった。しかし，動物が撮影され た巣のすべてで，次の日に巣の中の卵の消失また は中身のない卵の殼を確認した。森林の 1 巣では 巣内が空となっていた。藪4ヶ所のうち3 所で は, 巣内や巣近くの地面に卵の款がみられ，1ケ所 では巣内に噛み跡のついた中身のない卵殼がみら れた。 草原の 1 巣では巣内に細かい卵の殼の破片 がみられた。森林で撮影されたハシブトガラスと クマネズミについては, クマネズミが 6 月 13 日の 21:03 に巣の中に入る様子が撮影され，6月14日 の 11:35 にハシブトガラスが巣を覗く様子が撮影 されていた。卵の消失は 6 月 14 日の 15〜16 時の 間に確認した。

\section{考察}

擬巣は実際に鳥が営む巣とは異なり，親鳥の行 動や雛の飭乞い声によって捕食者を誘引すること がなく (Haskell 1994, Leech \& Leonard 1997, Martin et al. 2000)，擬巣が捕食される割合を直ちに実際 の巣に当てはめることはできない (Wilson et al. 1998, Zenette 2002). しかし，どのような生息場所 で，あるいはどのような巣場所の特性が巣の捕食 に影響しているかを知るには，統制された条件で 設置した擬巣の捕食状況を比較することが役立つ (Zenette 2002, Hamao et al. 2009). そのため, 今回 の擬巣実験においても喜界島での営巣環境の違い による捕食されやすさの違いや，捕食の受けやす さの要因による影響を知ることができる.

喜界島における擬巣実験の結果では，メジロ， ウグイス, セッカの営巣環境である森林, 藪, 草 原の間で巣の生残確率, 捕食される割合が異なる ことがわかった（図 2)。特に，森林において，藪 や草原よりも巣が捕食されやすかった，巣場所の 特性の一つである巣の隠蔽度について, 各環境内 での捕食された巣とされなかった巣の間で見えや すさを比較すると，三つの環境すべてにおいて違 いがみられなかった。しかし三つの環境間で巣の
上からと横からの隠蔽度を比較すると, 三つの環 境の中で草原は上から最も見えやすく, 森林は横 から最も見えやすいことがわかった。

捕食者としては，ハシブトガラス，クマネズミ， ニホンイタチが撮影された。二例では，実際に卵 をくわえている状態が撮影されており，喜界島に おいて移入哺乳動物が鳥の巣を捕食することが明 らかとなった。また，他のすべての例で捕食者が 撮影された翌日に卵の消失や中身のない卵殼を確 認しており，撮影されたこれらの動物が卵を捕食 したものと考えられる。森林では1 回の撮影でハ シブトガラスとクマネズミの 2 種が巣を訪れる様 子が撮影され，その巣の卵が捕食された。抏そら く先に巣へ訪れたクマネズミによる捕食と考えら れるが, ハシブトガラスも森林内で捕食者となっ ている可能性が高い.

擬巣実験において森林の擬巣が捕食されやす かった理由として，森林に生息する捕食者の影響 が考えられる。森林では捕食者としてハシブトガ ラス，クマネズミが撮影された。 ハシブトガラス は，擬巣実験の期間中にほとんどの森林で姿や鳴 き声を確認し，森林のいたる所にハシブトガラス が生息していた，そのため，森林の多くの擬巣を 捕食された可能性が考えられる。ささらに, 他の環 境で撮影されたニホンイタチは木に登り鳥の巣を 捕食することが知られており (山本 2006), 二ホ ンイタチが林内に走り込むのも観察されており (坂上 個人的観察), 二ホンイタチによる捕食も起 きている可能性がある。このように，森林では哺 乳動物, ハシブトガラスと, 他の環境に比べ多く の捕食者が巣を襲うことによって，捕食の割合が 高くなった可能性が考えられる。また捕食に関わ る重要な要因として隠蔽度があり，隠蔽された見 えにくい巣ほど捕食されにくいことがわかってい る (Ueta 1998, Kleindorfer et al. 2003, Mizuta 2009). 今回の擬巣実験の結果, 環境内での個々の巣の見 えやすさは捕食の有無に関係が見られなかった。 しかし，三つの環境間での見えやすさの比較では 森林が横から最も見えやすいことがわかった。こ のことから森林は，他の環境より巣が見えやすく 捕食の割合が高くなった可能性も考えられる.

捕食者はその生息場所にある鳥の巣を繰り返し 襲うことがある（Weidinger \& Kocvara 2010）。一 度, ある夕イプの巣を捕食したことによって, 捕 食者が具体的な巣の場所や巣のタイプに対する探 索イメージを学習し, 他の巣の発見が容易になる 可能性が知られている（Martin 1988, Borgmann \& 
Rodewald 2004)。 そのため, 捕食された巣の近く にある巣は，捕食者に発見され，捕食を受けやす いことが予想される。 今回, 擬巣の設置の際に森 林は藪や草原に比べ少なく, 一部で広い面積を占 めていたために, 連続して森林に擬巣を設置した 場所があり（図 1)，そのために森林での捕食者 が, 連続する擬巣を次々と見つけ出し捕食した可 能性が考えられる。確かに, 調査地全体では捕食 された擬巣の近くにある擬巣が捕食されやすかっ たので，捕食者が学習に基づいて巣の探索をする 可能性が考えられる。しかし，森林で捕食された 擬巣の近くで捕食が起こりやすいということは見 られず，また森林では他の営巣環境よりも捕食さ れた巣間の距離が短いということもなかった（図 3). したがって, 捕食者の学習が森林で捕食が起 こりやすいことの主要な要因とは考えられない.

これらのことから, 今回森林で捕食された擬巣 の割合が他の環境よりも高くなったのは，捕食者 の種数の多さが影響したと考えられる。そのため, 実際の巣に扔ける環境による捕食の割合の違いは, 営巣環境の植生に対応して生息する捕食者の種数 や生態によって生じる可能性が考えられる。 また, 隠蔽度の低い営巣環境では捕食の割合が高くなる 可能性が考えられる.

環境内の個々の巣の隠蔽度が捕食されやすさに 関係がなかったことは，捕食者にとって，見えや すさが巣の探索の手がかりとしてあまり重要では ないことを示唆している。 今回捕食者として考元 られるクマネズミは一般的に, 嗅覚, 聴覚, 触覚 などの感覚が優れており（デュボック 1986）, 視 覚以外の感覚も使い巣を探していると考えられる。 また，クマネズミとニホンイタチは全て日が暮れ てから撮影されたため, 両者は視覚による巣の探 索に加え，嗅覚などによって巣を発見した可能性 も考えられる。これらのことから，実際の鳥類が 少し見えにくい場所に営巣したとしても, 営巣環 境にネズミ類やニホンイタチのような夜行性の捕 食者が生息する場合，巣は捕食されてしまうと考 えられる。

今回の喜界島での擬巣実験によって森林の巣が 捕食されやすいことが示された。このことから， 実際に喜界島の森林で営巣する亜種リュウキュウ メジロの個体群維持に，捕食者による影響がある 可能性が示唆される。 また, 森林の巣の捕食率は 藪や草原よりも高く, 森林で撮影された在来種で あるハシブトガラスによる捕食の割合が高い可能 性が考えられる。一方，藪と草原は捕食率が低
かったが，ハシブトガラスは撮影されずハシブト ガラスによる捕食の影響は少ないと考えられる. 喜界島の藪と草原に営巣するウグイスとセッカは 移入種の侵入以前はほとんど捕食者がいなかった と考えられ, 移入哺乳動物が侵入したことの影響 が大きくある可能性が考えられる.

また捕食者撮影で特定されたクマネズミは島の 三つの代表的な環境全てにおいて撮影され，島の 広範囲にわたり生息していることが推測される. そのため, 喜界島の鳥類の巣へのクマネズミによ る捕食の影響の可能性は大きいと考えられる。海 外の熱帯・亜熱帯地域を中心とした島嶼において は, 外来のネズミ類の生態系への影響の強さが問 題視されている（橋本 2009）。 また最近の日本に おける移入種問題でも小笠原諸島におけるクマネ ズミによる海鳥類の捕食問題（堀越ら 2009）や, 奄美大島でのクマネズミ増加による生態系への影 響（石田ら 2003）などクマネズミが問題となる ケースが報告されている。実際に喜界島において クマネズミが鳥類の個体群の維持に影響を及ぼす ほど捕食または生息しているかは定かではないが, 移入種の問題に扔いて, クマネズミはこれから注 目していく必要があるだろう。

現地の調查にあたって喜界町役場の方々には便宜を 図って頂いた。喜界町役場の伊地智告氏には喜界島の植 生について教えて頂いた。研究計画の際には立教大学動 物生態学研究室の皆さんに多くのアドバイスを頂いた. また調査の際にはデジタルセンサーカメラを貸して頂い た。国立科学博物館動物研究部の川田伸一郎研究員には 哺乳類の同定の助言を頂いた。 編集幹事と匿名査読者に は原稿の改訂に役立つ有益なコメントを頂いた。多くの 方々の陰で行う事ができた研究である。これらの方々 に深く感謝したい.この研究は国立科学博物館総合研究 「変動する地球環境下における生物多様性の成立と変遷」 の一環として行われた。

\section{摘要}

鳥の営巣環境間での捕食率の違いの調査と捕食 者を特定するために奄美諸島喜界島で擬巣実験を 行った，擬巣実験によって捕食された巣の割合と 生残確率の両方で, 森林の巣が藪と草原の巣より 容易に捕食されることが示唆された。また自動撮 影装置を設置した擬巣では移入哺乳動物（クマネ ズミRattas rattas とニホンイタチ Mustela itatsi) と ハシブトガラス Corvus macrorhynchos が捕食者と なっていることが明らかとなった，個々の巣の隠 蔽度または巣間の距離は捕食との間に統計的に有 意な関係が見出されなかった，森での頻繁な巣の 
捕食は, 環境内の捕食者種の多さと生態によって 生じる可能性が考えられる.

\section{引用文献}

Blackburn TM, Cassey P, Duncan RP, Evans KL \& Gaston KJ (2004) Avian extinction and mammalian introductions on oceanic islands. Science 305: 1955-1985.

Borgmann KL \& Rodewald AD (2004) Nest predation in an urbanizing landscape: the role of exotic shrubs. Ecol. Appl. 14: $1757-1765$.

Courchamp F, Chapuis J-L \& Pascal M (2003) Mammal invaders on islands: impact, control and control impact. Biol. Rev. 78: 347-383.

デュボック AC (1986) げっ歯目総論. マクドナルド DW (編) 動物大百科第 5 巻小型草食獣：6-15. 平凡社, 東京.

Dutton J (1994) Introduced mammals in Sao Tome and Principe: possible threats to biodiversity. Biodiv. Conserv. 3: 927-938.

Hamao S, Nishimatsu K \& Kamito T (2009) Predation of bird nests by introduced Japanese Weasel Mustela itatsi on an island. Ornithol. Sci. 8: 139-146.

濱尾章二 (2009) 巣内に設置した温度データロガーによ るダイトウウグイスの繁殖経過の推定. 自然教育園報 告 $(40): 73-81$.

Haskell D (1994) Experimental evidence that nestling begging behaviour incurs a cost due to nest predation. Proc. R. Soc. Lond. B 257: 161-164.

橋本环磨 (2009) 小笠原におけるネズミ類の根絶とその 生態系に与える影響. 地球環境 14: 93-101.

堀越和夫 · 鈴木 創 · 佐々木哲郎 · 千葉勇人 (2009) 外 来哺乳類による海鳥類への被害状況. 地球環境 14 : 103-105.

石田 健 · 宮下 直 ·山田文雄 (2003) 群集動態を考慮 した生態管理の課題と展望 : 奄美大島における外来種 問題の事例. 保全生態学研究 8: 159-168.

金子之史 (2006) ネズミの分類学. 東京大学出版会, 東 京.

清棲幸保 (1978) 日本鳥類大図鑑。講談社, 東京.

Kleindorfer S, Fessl B \& Hoi H (2003) The role of nest site cover for parental nest defence and fledging success in two Acrocephalus warblers. Avian Science 3: 21-29.

Leech SM \& Leonard ML (1997) Begging and the risk of predation in nestling birds. Behav. Ecol. 8: 644-646.

Martin TE (1988) On the advantage of being different: nest predation and the coexistence of bird species. Proc. Natl.
Acad. Sci. USA 85: 2196-2199.

Martin TE, Scott J \& Menge C (2000) Nest predation increases with parental activity: separating nest site and parental activity effects. Proc. R. Soc. Lond. B 267: 22872293.

Mayfield HF (1961) Nesting success calculated from exposure. Wilson. Bull. 73: 255-261.

Mayfield HF (1975) Suggestions for calculating nest success. Wilson. Bull. 87: 456-466.

三井喜禎 (1965) 喜界島古今物語. 三晃印刷, 東京.

Mizuta T (2009) Nest-site characteristics affecting the risk of nest predation in the Madagascar Paradise Flycatcher Terpsipfone mutata: identification of predators and time of nest predation. Ornithol. Sci. 8: 37-42.

尾崎清明 - 馬場孝雄 - 米田重玄 ·金城道男 - 渡久地 豊・原戸鉄二郎 (2002) ヤンバルクイナの生息域の減 少. 山階鳥研報 34: 136-144.

Rice WR (1989) Analyzing tables of statistical tests. Evolution 43: 223-225.

高木昌興・樋口広芳 (1992) 伊豆諸島三宅島におけるア カコッコ Turbus celaenops の環境選好とイタチ放獣の 影響. Strix 11: 47-57.

Uchida TA (1969) Rat-control procedures on the Pacific islands, with special reference to the efficiency of biological control agents. J. Fac. Agric. Kyushu Univ. 15: 355385.（この文献は直接参照できなかったので, 阿部ら (1991) から引用した。 阿部慎太郎・高槻義隆・半田ゆ かり・和 秀雄 (1991) 奄美大島におけるマングース (Herpestes sp.) の定着. 哺乳類科学 31: 23-36.)

Ueta M (1998) Azure-winged Magpies avoid nest predation by nesting near a Japanese Lesser Sparrowhawk's nest. Condor 100: 400-402.

Weidinger K \& Kocvara R (2010) Repeatability of nest predation in passerines depends on predator species and time scale. Oikos 119: 138-146.

Wilson GR, Brittingham MC \& Goodrich LJ (1998) How well do artificial nests estimate success of real nest? Condor 102: 256-266.

Whittingham MJ \& Evans KL (2004) The effects of habitat structure on predation risk of birds in agricultural landscapes. Ibis 146: 210-220.

山本 裕 (2006) アカコッコ。 バードリサーチニュース 3: 4-5.

安間繁樹 (2001) 琉球列島: 生物の多様性と列島のおい たち。東海大学出版会, 東京.

Zanette L (2002) What do artificial nests tell us about nest predation? Biol. Conserv. 103: 323-329. 